\title{
Iron Balance in Regular Blood Donors
}

\author{
Zahra Mozaheb Mohamad Khayami Delaram Sayadpoor \\ Department of Hematology-Oncology of Mashhad University of Medical Science, Blood Transfusion Organization of Mashhad, Iran
}

\section{Keywords}

Blood donation · Iron deficiency · Iron balance · Ferritin

\section{Summary}

Background: Numerous reports have shown that iron stores decrease in blood donors after donation. As we need healthy donors, it is essential to test hemoglobin and ferritin levels for preventing reduced of iron stores in donors. Methods: This study was conducted on 235 healthy men. The donors were divided into three groups: group I) control group with no donation; group II) case group 1 with two donations within 1 year; group III) case group 2 with three donations within 1 year. Results: The mean level of hemoglobin was 15.9 and $14.7 \mathrm{~g} / \mathrm{dl}$ in the control group and in the case group, respectively $(p<0.0000)$. The mean level of serum ferritin in group I, II and III, was 108, 56 and $26 \mu \mathrm{g} / \mathrm{l}$, respectively $(p<0.0000)$. When studying various stages of iron deficiency in donors, it could be shown that $58 \%$ of group III donors but only $1 \%$ of control group donors had a negative iron balance. Moreover, iron deficiency anemia was observed in $20 \%$ of group III donors. Conclusion: Just measuring the hemoglobin level is not sufficient for selecting donors. In addition, testing of the ferritin level and iron supplementation are recommended in regular donors with more than one donation per year.

\author{
Schlüsselwörter \\ Blutspende · Eisenmangel · Eisenbalance · Ferritin
}

\section{Zusammenfassung}

Hintergrund: Eine Vielzahl von Studien hat gezeigt, dass die Eisenspeicher von Blutspendern nach einer Spende reduziert sind. Da wie gesunde Spender brauchen, ist es von essentieller Bedeutung, die Hämoglobin- und Ferritinkonzentrationen zu prüfen, um eine Reduzierung der Eisenspeicher zu vermeiden. Methoden: In dieser Studie wurde 235 gesunde Männer untersucht. Die Spender wurden in 3 Gruppen unterteilt: Gruppe I) Kontrollgruppe ohne Spende, Gruppe II) Studiengruppe I mit 2 Blutpenden pro Jahr, Gruppe III) Studiengruppe 2 mit 3 Blutspenden pro Jahr. Ergebnisse: Die mittlere Hämoglobinkonzentration war $15,9 \mathrm{~g} / \mathrm{dl}$ in der Kontrollgruppe und $14,7 \mathrm{~g} / \mathrm{dl}$ in den beiden Studiengruppen ( $p=0,0000$ ). Die mittlere Serum-Ferritinkonzentration in Gruppe I, II bzw. III betrug 108, 56 bzw. $26 \mu \mathrm{g} / \mathrm{l}(\mathrm{p}=0,0000)$. Bei der Untersuchung der verschiedenen Stadien des Eisenmangels bei den Spendern ließ sich zeigen, dass 58\% der Gruppe-III-Spender, aber nur 1\% der Gruppe-I-Spender eine negative Eisenbalance aufwiesen. Darüber hinaus wurde bei der $20 \%$ der Gruppe-III-Spender eine Eisenmangelanämie festgestellt. Schlussfolgerung: Für die die Spenderselektion ist die alleinige Messung der Hämoglobinkonzentration nicht ausreichend. Zusätzlich wird bei regelmäßigen Spendern mit mehr als einer Blutspende pro Jahr die Bestimmung der Ferritinkonzentration sowie die Verabreichung von Eisensupplementen empfohlen.

\begin{tabular}{ll}
\hline KARGER & @ 2011 S. Karger GmbH, Freiburg \\
Fax +497614520714 & Accessible online at: \\
Information@Karger.de & www.karger.com/tmh \\
www.karger.com &
\end{tabular}

Dr. Zahra Mozaheb

Department of Hematology-Oncology,

Mashhad University of Medical Science

Mashhad, Iran

Tel. +98 511-7636286, Fax -8444497

mozahebz@mums.ac.ir 


\section{Introduction}

The safety of blood supply depends on healthy individuals who can cope regular blood donation. The donation of one blood unit will result in the loss of about $242 \pm 17 \mathrm{mg}$ of iron in males [1]. Iron stores are adequate between the first and second donations. However, in blood donors with high frequency in donation, iron stores decrease because of negative iron balance. In addition, continuous donation can cause iron deficiency and anemia [2]. The frequency of donations during 1 year is more predictive for a decreased ferritin level than the number of lifetime donations, and an increase in donation frequency in 1 year was accompanied by a significant decrease of the iron stores [3]. Blood centers use hemoglobin concentration to estimate iron state even though hemoglobin may be normal in donors with depleted iron stores. The most useful and sensitive indicator for measurement of body iron is the plasma ferritin concentration [4]. In this study, the need for testing the serum ferritin was evaluated. Blood donors were screened for identifying those with low serum ferritin but normal hemoglobin level.

\section{Material and Methods}

A total 235 blood donors, who visited in the Mashhad blood transfusion center from September 2009 to March 2010, were studied. Donors were divided into three groups: group $\mathrm{I}=$ control group with no donation $(\mathrm{n}=79)$, group II with two donations per year $(\mathrm{n}=82)$, and group III with three donations per year $(n=74)$. Groups II and III were also called case groups. Inclusion criteria were based on the instruction of the Iranian Ministry of Health for blood donation, i.e. hemoglobin values more than $12.5 \mathrm{~g} / \mathrm{dl}$, age between 17 and 65 years, weight more than $50 \mathrm{~kg}$, one previous donation of more than 8 weeks earlier. Moreover, donors who had taken iron supplement were excluded from the study. Women were also excluded from the study since most of them were on iron supplement previously.

This study was approved by the Institutional Ethic Committee of Mashhad University of Medical Science. Personal information including age and history of previous donations over a one year period was recorded, too. Prior to blood donation, roughly $8 \mathrm{ml}$ of blood was taken from each donor for testing. A complete blood count (CBC) was performed using an automatic Beckman Coulter device (T860; Beckman Coulter GmbH, Krefeld, Germany), and serum ferritin concentration was measured by the ELISA technique using RADIM kit (Radim Deutschland $\mathrm{GmbH}$, Freiburg i.Br., Germany).

Reduction of iron stores was considered as a negative iron balance below $20 \mu \mathrm{g} / \mathrm{l}$ and iron-deficient erythropoiesis was considered for serum ferritin concentrations below $15 \mu \mathrm{g} / \mathrm{l}$ [5]. In addition, iron deficiency anemia was defined as serum hemoglobin and ferritin below $13 \mathrm{~g} / \mathrm{dl}$ and $15 \mu \mathrm{g} / \mathrm{l}$, respectively.

For statistical analysis t test, and ANOVA test were performed using SPSS 13.0 (Chicago, IL, USA).

\section{Results}

The donors were between 24 and 65 years of age. Most of the donors $(61.9 \%)$ were between the age of 41 to 60 years. The

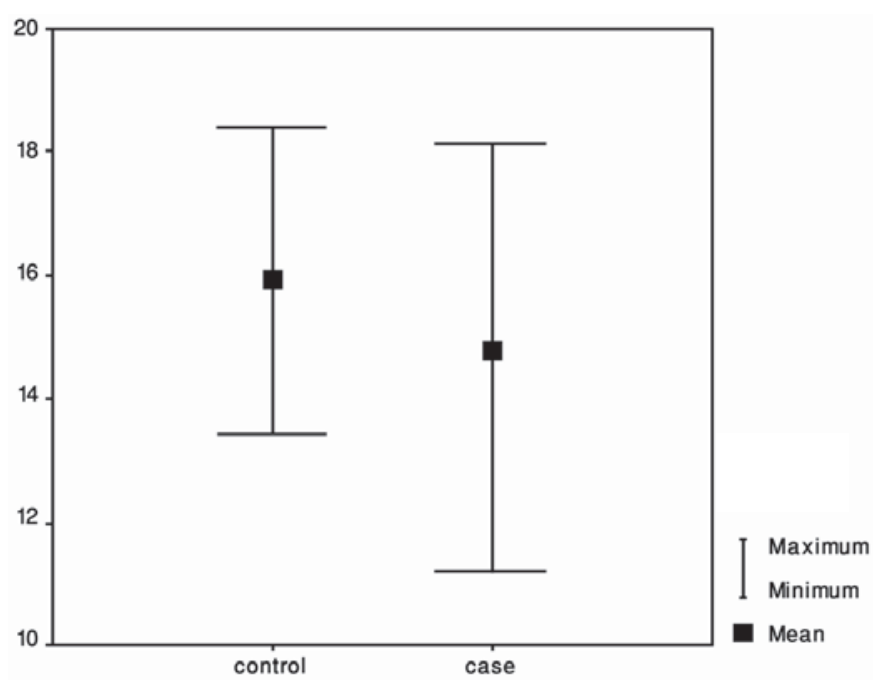

Fig. 1. Mean hemoglobin levels in the control and case groups.

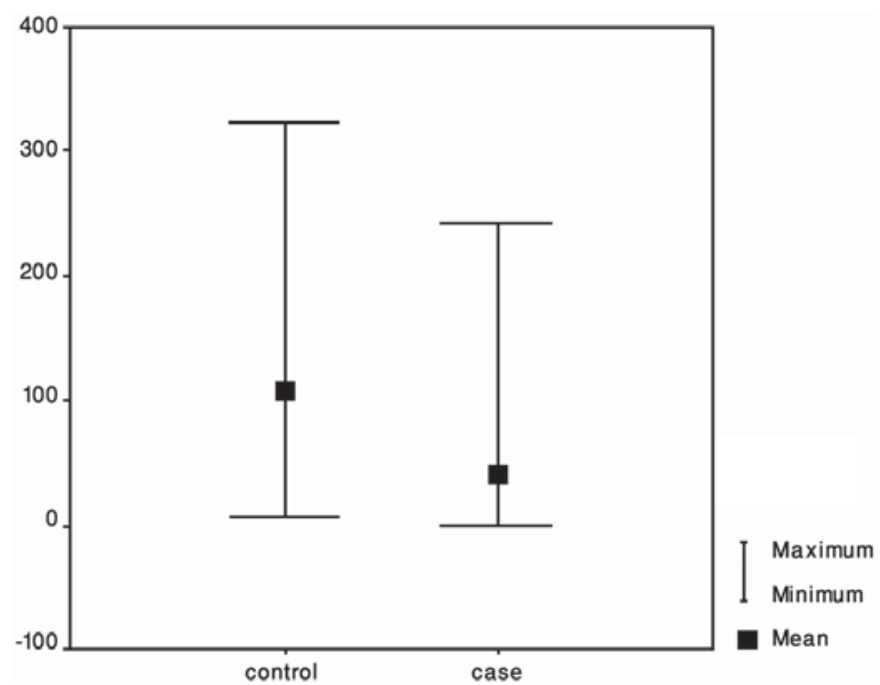

Fig. 2. Mean ferritin levels in the control and case groups.

mean age of group I (control group), group II and group III (case groups) was 55.2, 50.0 and 48.5 years, respectively. The mean age in the case groups was 58.5 years.

Analysis of hemoglobin, mean corpuscular volume (MCV) and ferritin level in the control group and in the case groups indicated that hemoglobin, and ferritin levels as well as MCV decreased with the increasing number of donations during 1 year. As illustrated figure 1, the mean hemoglobin concentrations were $15.9 \pm 1.0 \mathrm{~g} / \mathrm{dl}$ in the control group $(\mathrm{n}=79)$ and $14.7 \pm 1.6 \mathrm{~g} / \mathrm{dl}$ in the case groups $(\mathrm{n}=156)$. This difference between the control and the case groups was statistically significant $(\mathrm{p}=0.0000)$.

The mean ferritin level in the control group $(\mathrm{n}=80)$ and the case groups $(\mathrm{n}=156)$ was $108 \pm 77$ and $42 \pm 31 \mu \mathrm{g} / \mathrm{l}$, resepectively, and showed also statistically significant difference $(\mathrm{p}=0.0000)$ (fig. 2). 


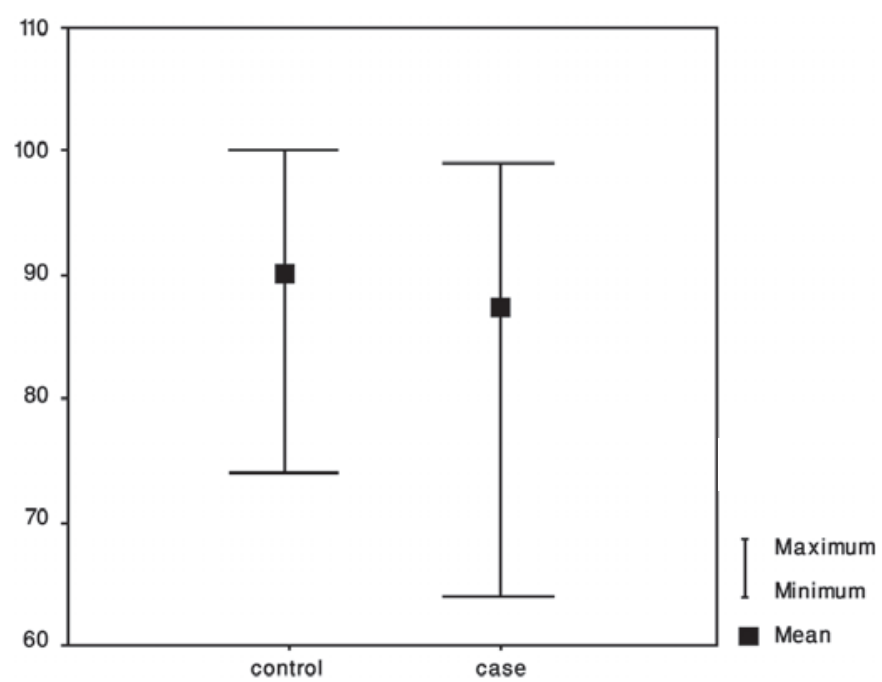

Fig. 3. Mean MCV levels in the control and case groups.

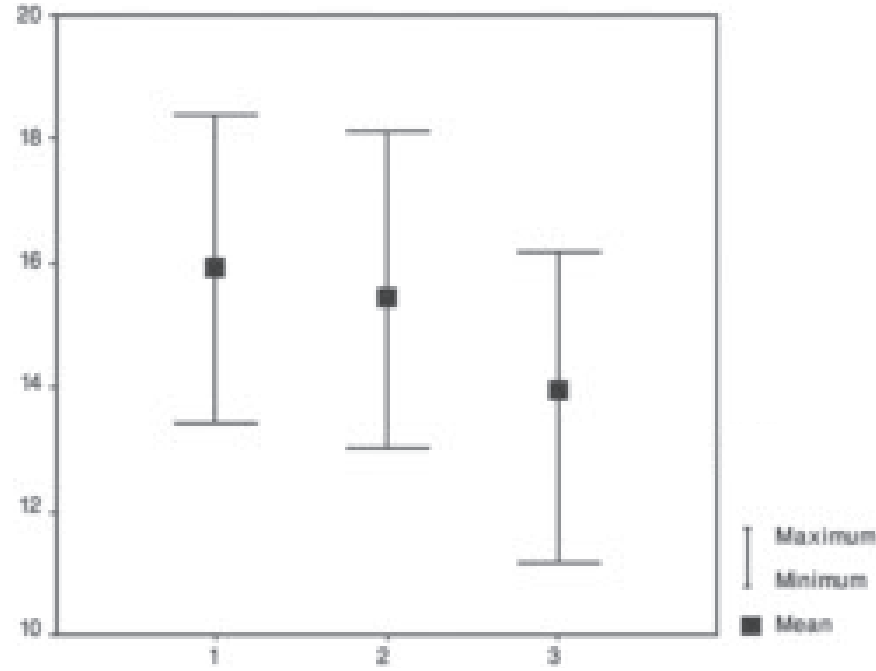

Fig. 4. Mean and variation level of hemoglobin in the three groups.

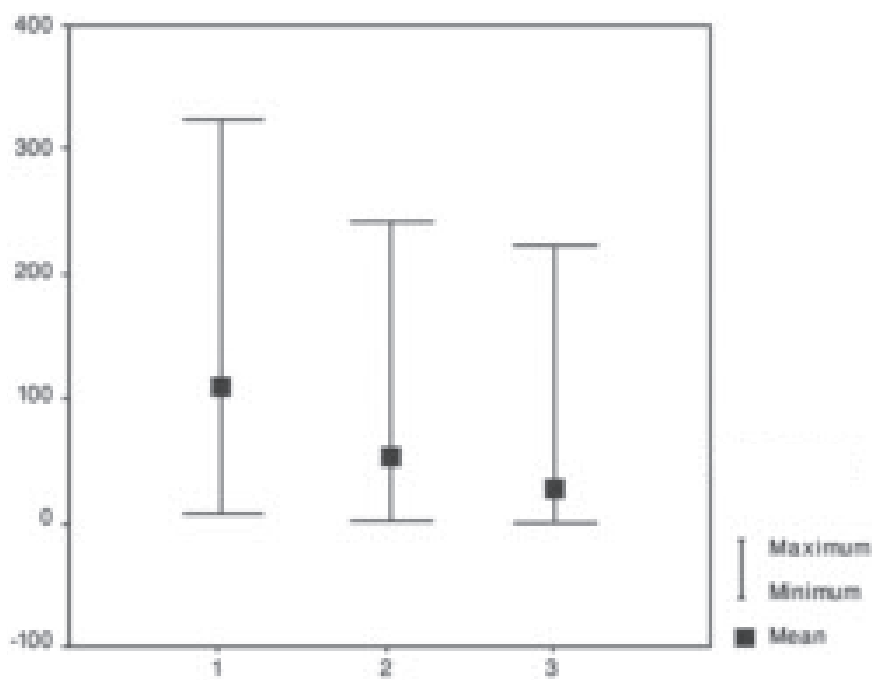

Fig. 5. Mean and variation level of ferritin in the three groups.

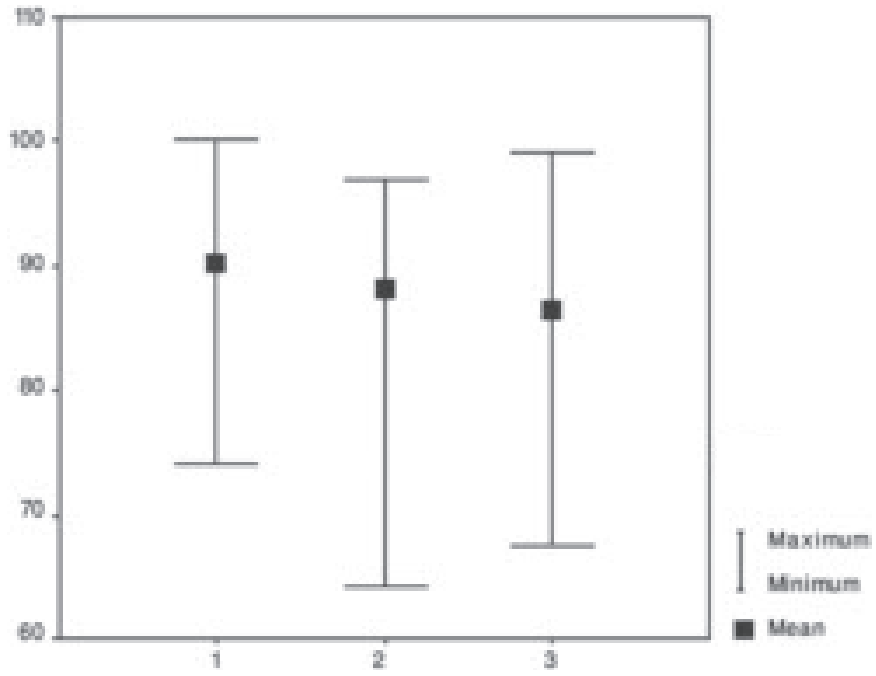

Fig. 6. Mean and variation level of MCV in the three groups.
Table 1. Hemoglobin, ferritin and $\mathrm{MCV}$ in different groups

\begin{tabular}{lllll}
\hline Donors & $\mathrm{n}$ & $\begin{array}{l}\text { Hemoglobin } \\
\text { mean } \pm \text { SD (range) }\end{array}$ & $\begin{array}{l}\text { Ferritin } \\
\text { mean } \pm \text { SD (range) }\end{array}$ & $\begin{array}{l}\text { MCV } \\
\text { mean } \pm \text { SD (range) }\end{array}$ \\
\hline Group I & 79 & $15.9 \pm 1.0(13.4-18.4)$ & $108 \pm 77(8-323)$ & $90.0 \pm 4.2(74-100)$ \\
Group II & 82 & $15.4 \pm 1.1(13.0-18.0)$ & $56 \pm 52(4-243)$ & $88.0 \pm 4.6(64-97)$ \\
Group III & 74 & $13.8 \pm 1.6(12.0-16.2)$ & $26 \pm 33(2-223)$ & $86.4 \pm 6.5(67-99)$ \\
\hline
\end{tabular}

The mean MCV levels were $90.0 \pm 4.2 \mathrm{fl}$ in the control group $(\mathrm{n}=80)$ and $87.3 \pm 5.6 \mathrm{fl}$ in the case groups $(\mathrm{n}=156)$ which was found to be statistically significant too $(p=0.0000)$ (fig. 3$)$.

When comparing the mean levels of hemoglobin, ferritin and MCV in groups I, II and III by a one-way ANOVA test, statically significant differences between groups could be shown ( $\mathrm{p}=0.000)$ (fig. 4, 5, 6).
As illustrated in table 1, all three parameters were reduced with increasing number of donations per year. However, our data show the decrease in serum ferritin was by far the most prominent, especially when compared with the decrease in hemoglobin levels.

As shown in table 2, without donation only $0.9 \%$ of donors had a negative iron balance, $0.6 \%$ had iron-deficient erythro- 
Table 2. Effect of blood donation on iron status

\begin{tabular}{lclll}
\hline & $\begin{array}{l}\text { Group I } \\
\mathrm{n}(\%)\end{array}$ & $\begin{array}{l}\text { Group II } \\
\mathrm{n}(\%)\end{array}$ & $\begin{array}{l}\text { Group III } \\
\mathrm{n}(\%)\end{array}$ & p value \\
\hline Number of donors & $82(100)$ & $79(100)$ & $74(100)$ & \\
Negative iron balance* & $8(0.9)$ & $20(26)$ & $43(58)$ & $<0.0001$ \\
Iron-deficient erythropoiesis** & $5(0.6)$ & $12(15)$ & $38(51)$ & $<0.0001$ \\
Iron deficiency anemia*** & - & - & $15(20)$ & $<0.0001$ \\
MCV < 80 & $1(0.01)$ & $1(0.01)$ & $8(11)$ & 0.004 \\
\hline Ferritin $<20 \mu \mathrm{g} / \mathrm{l}[5]$. & & & \\
$* *$ Ferritin $<15 \mu \mathrm{g} / \mathrm{l}$. & & & \\
$* * *$ Ferritin $<15 \mu \mathrm{g} / \mathrm{l}$, hemoglobin $<13 \mathrm{~g} / \mathrm{dl}[1]$. & & & \\
\hline
\end{tabular}

poiesis, and no participant presented with iron deficiency anemia. However, in group II there were $26 \%$ with negative iron balance and $15 \%$ with iron-deficient erythropoiesis, and in group III negative iron balance was detected in 58\%, irondeficient erythropoiesis in $51 \%$ and iron deficiency anemia in $20 \%$ of the donors. Consequently, we found that after the second donation within 1 year, iron stores decreased significantly.

\section{Discussion}

Although several studies have indicated that repeated blood donation induces iron depletion and iron deficiency, all blood centers still test only hemoglobin as an indicator for selecting the donors [1]. Therefore, we decided to show the importance of measuring the iron stores and then proposed a strategy to prevent severe iron depletion during frequent donations.

As shown in figures 1, 2 and 3 as well as in table 1, the donation frequency increases the levels of hemoglobin, ferritin and MCV decreases. The mean hemoglobin concentration in the control group was $15.9 \pm 1.0 \mathrm{~g} / \mathrm{dl}$; in the case groups it was $15.4 \pm 1.1 \mathrm{~g} / \mathrm{dl}$ in group II and $13.8 \pm 1.6 \mathrm{~g} / \mathrm{dl}$ in group III. These differences between the three groups were statistically significant $(\mathrm{p}=0.0000)$. The mean ferritin level in group I, II and III was $108.1 \pm 77,56 \pm 52$ and $26 \pm 33 \mu \mathrm{g} / \mathrm{l}$, respectively $(\mathrm{p}=0.0000)$. With respect to the MCV levels the differences between the three groups were also statistically significant $(p=0.0000)$. Comparison of hemoglobin and ferritin levels in different age groups showed a downward trend in all ages, and no difference was found between ages. These data illustrated that repeated blood donation had a significant effect on the iron balance in all donors.

As shown in table 2 , about $58 \%$ of donors in group III, who had three donations per year, were diagnosed with negative iron balance, $51 \%$ with iron-deficient erythropoiesis and $20 \%$ with iron deficiency anemia. In contrast, in group I less than $1 \%$ showed negative iron balance and iron-deficient erythropoiesis, and no iron deficiency anemia was detected $(\mathrm{p}=0.0001)$.

Other studies [6] demonstrated that iron deficiency was present in $14 \%$ of men who had four or more blood dona- tions during 1 year. In addition Djalali et al. [7] revealed that the frequency of blood donation per year was inversely correlated with hemoglobin, hematocrit, mean corpuscular hemoglobin concentration and serum ferritin. Mittal et al. [1] also showed that an increase in donation frequency was accompanied by a significant decrease in serum ferritin; serum ferritin below $15 \mu \mathrm{g} / \mathrm{l}$ was found in $49 \%$ of male and $100 \%$ of female donors who donated thrice per year. Cancado et al. [8] found that the frequency of iron deficiency was higher among male donors with three or more donations per year and among the women with two or more donations per year. The results of all these studies were similar to our findings and showed the importance of measuring iron stores as an indicator for being selected for blood donation.

Iron-depleted and iron-deficient donors are often annoyed and might become reluctant to donate again, even if they had been regular blood donors. On the other hand, we need a safe and effective donation; therefore, blood centers should consider consultation and iron replacement also for men, and not only for women, in order to retain the volunteer donor base [4].

Several studies have found a rapid recovery of hemoglobin in autologous blood donors with iron deficiency anemia who had been supplemented with a daily dose of $200 \mathrm{mg}$ iron [4, 9].

From other studies [10-12] we know that iron replacement may be associated with some problems such as need of new section to deal with donors in the blood center setting, concern about missing underlying disease such as gastrointestinal disease, increase of iron overload resulting in hemochromatosis, and the belief that donors with lower iron stores might be healthier, particularly with regard to atherosclerosis and the risk of cardiovascular events. Thus a protocol is required for iron replacement. For example, donors who are iron-depleted and have a first-degree relative under the age of 60 years diagnosed with colorectal, small bowel, ureteral and/or in some instances pancreatic cancers, or donors who have multiple family members with cancer should not receive iron supplement before further evaluation and screening test [4]. Consequently, based on these controversies, such a protocol should consider advantages and disadvantages of iron replacement. However, we should keep in 
mind that iron therapy is not dangerous. If iron deficiency was approved, it is necessary to start iron replacement. Since iron stores are reduced by about $200 \mathrm{mg}$ iron per donation and with respect to an of iron absorption rate of usually $10-20 \%$ [13], the recommended dosage of iron supplementation is roughly $100 \mathrm{mg}$ /day for 10-20 days after the blood donation.

Because ferrous sulfate is associated with gastrointestinal side effects and poisoning in children who have access to the medication, some researchers suggest to use iron carbonil which is not associated with gastrointestinal side effects or poisoning $[4,14]$.

\section{Conclusion}

i) Reduction of iron stores after blood donation increases by frequent donations, and induces iron depletion and iron deficiency anemia.

ii) Just determining the serum hemoglobin is not a good measure for the state of iron stores, and it is not sufficient to ascertain the ability for donation. iii) Measuring the ferritin level is the best test to evaluate the iron stores and can be used as a criterion to ascertain the donor's aptitude.

Measurement of serum ferritin is recommended when more than 1 donation is given per year. Furthermore, donors who donate more than once a year should receive iron supplement, except for those having multiple family members with cancer or a first-degree relative under the age of 60 years diagnosed with listed cancer.

\section{Acknowledgment}

We would like to acknowledge the support of the Research Center of the Iranian Blood Transfusion Organization NO: 511/2277. We also thank the personnel of the Mashhad Blood Transfusion Center Dr. Shahabi, Dr. Bazargani, Dr. Jalalian, Mr. Taleshi, and Dr. Afzalaghaee, Ms N. Saberi for their cooperation in this study.

\section{Disclosure Statement}

The authors declare no conflict of interest.

\section{References}

1 Mittal R, Marwaha N, Basu S, Mohan H, Ravi Kumar A: Evaluation of iron stores in blood donors by serum ferritin. Indian J Med Res 2006;124: 641-646.

2 Javadzadeh Shahshahani H, Attar M, Taher Yavari M: A study of prevalence of iron deficiency and its related factors in blood donors of Yazd, Iran, 2003. Transfus Med 2005;4:287-293.

$\checkmark 3$ Milman N, Søndergaard M. Iron stores in male blood donors evaluated by serum ferritin. Transfusion 1984;6:464-468.

4 Bianco C, Brittenham G, Gilcher RO, Gordeuk VR, Kushner JP, Sayers M, Chambers L, Counts RB, Aylesworth C, Nemo G, Alving B: Maintaining iron balance in women blood donors of childbearing age: summary of a workshop. Transfusion 2002;42:798-805.

5 Adamson JW: Iron deficiency anemia and other hypoproliferative anemia: in Fauci A, Braunward E, Kasper DL, Hauser SL, Longo DL, Jameson JL, Loscalzo J (eds): Harrison's Principles of Internal Medicine. 17th ed New York, Mc Graw Hill, 2008, pp 628-634.
6 Hernandez Lamas MC, Lopez Perez-Lanzac JC, Prat Arrojo I, Sanchea Gordo F, Arleth Christensen E, Sanchez Font E: Determination of serum ferritin: ideas for avoiding induction ferropenia in blood donors. Sangre (Barc) 1994;39:9-14.

7 Djalali M, Neyestani TR, Bateni J, Siassi F:: The effect of repeated blood donations on the iron status of Iranian blood donors attending the Iranian blood transfusion organization. Int J Vitam Nutr Res 2006;76:132-137.

8 Cançado RD, Chiattone CS, Alonso FF, Langhi Júnior DM, Alves Rde C: Iron deficiency in blood donors. Sao Paulo Med J 2001;119:132-134.

9 Alvares-Ossorio L, Kirchner H, Klüter H, Schlenke $\mathrm{P}$ : Low ferritin levels indicate the need for iron supplementation: strategy to minimize iron-depletion in regular blood donors. Transfus Med 2000;10:112116.

10 Simon TL: Iron, iron everywhere but not enough to donate. Transfusion 2002;42:664-665.
1 Meyers DG: The iron hypothesis: does iron play a role in atherosclerosis? Transfusion 2000;40:10231029.

12 Van Hoydonck PG, Schouten EG, Hoppenbrouwers KP, Temme EH: Is blood donation induced low iron status associated with favourable levels of OxLDL, s-ICAM-1, sVCAM-1 and vWF-antigen in healthy men. Atherosclerosis 2004;172:321-327.

13 Schmidt LH, Gulich W, Schröder M, Drescher V: Iron resorption and the effects of iron supplementation in blood donors (in German). Folia Haematol Int Mag Klin Morphol Blutforsch 1990;117:823828.

14 Gordeuk VR, Brittenham GM, Bravo J, Hughes MA, Keating LJ: Prevention of iron deficiency with carbonyl iron in female blood donors. Transfusion 1990;30:239-245. 